\title{
Blood Donation Tested by Coronavirus Pandemy 2019 (Covid-19) in Cote d'Ivoire
}

\author{
Kambe Kambé Yves $^{1}$, Hyda Jules ${ }^{2}$, Diabate Songui ${ }^{3}$ \\ ${ }^{1}$ Ethno-Sociology Institute, Felix Houphouet Boigny University, Abidjan, Cote d'Ivoire \\ ${ }^{2}$ National Blood Transfusion Service (NBTS), Cote d'Ivoire \\ ${ }^{3}$ Ivorian Center for Economic and Social Research (CIRES), Felix Houphouet Boigny University, \\ Abidjan, Cote d'Ivoire \\ Email: kambekves@yahoo.fr,hyda_j@yahoo.fr,songuidiabate@gmail.com
}

\begin{abstract}
:
The 2019 coronavirus pandemic (covid-19), which spread rapidly around the world, has disrupted all organizations and led to a decline in their productivity. Their reorganization was therefore essential. The purpose of this study was to analyze the resilience strategies adopted by the National Blood Transfusion Service (NBTS) to reverse the trend of population participation. Thus, based on the qualitative approach centered on free interviews conducted with 30 people including 27 managers of Blood Transfusion Establishments (Blood Transfusion Center (BTC), Blood Transfusion Antenna (BTA) and Sampling Site (SS)), 2 heads of department (Communication and Coordination of services), the chairman of the scientific advisory council and a direct observation, of the theory of resilience and the systemic method, the analysis of the data indicates that the resilience strategies adopted by the NBTS are four: the dynamic communication on blood donation, rational blood using, the reorganization of blood collections in fixed site (Sundays and extension of the collection time) and the reorganization of mobile collections (fragmentation of mobile collection activities on site).
\end{abstract}

Keywords:

emerging diseases; covid-19; blood donation; resilience; blood collection

\section{Introduction}

For several years now, the world has been confronted with the (re)emergence of infectious diseases linked to the genetic plasticity of germs which allows them to adapt significantly to different situations (change of the ecosystem). Likewise, the incessant displacements, the development of megalopolises favor the pooling of microorganisms and opens up an immense field of opportunity for those with inter-human transmission. This is the case of coronavirus disease (covid-19), which was first reported in Wuhan, China on December 31, 2019.

Indeed, the covid-19 epidemic has been declared a "Public Health Emergency of International Concern (PHEIC)" (WHO, 2020), and the virus is now affecting many countries and territories. Although, many unknowns remain about the virus that causes covid-19, it has been reported that it is transmitted by direct contact with respiratory droplets produced by an infected person (when the person coughs or sneezes). A person may also be infected if they are in contact with contaminated surfaces or if they touch their face (e.g., eyes, nose or mouth).

Global data as of April 29, 2020, revealed 3,130,191 confirmed cases, 217,674 dead and 185 affected countries (Johns Hopkins University, 2020). 
As covid-19 continues to spread, it is essential that communities take action to prevent transmission of the virus and reduce the impact of the epidemic.

Thus, various measures called "barrier measures" were adopted, including physical and health measures. The first group of measures concerns the closure of the various borders (air, land and sea), the containment or quarantine, the state of emergency, the limitation of movements to essential activities, the closure of large-scale sites (theaters, cinemas, restaurants, schools and universities, etc.) and the prohibition of large-scale gatherings. The second type of measurement is related to the regular washing of hands with soap or with a hydro-alcoholic solution, the covering of the mouth and the nose with the bend of the elbow or a handkerchief in case of cough or sneezing, frequent cleaning of surfaces and objects touched, wearing of mask, respect a social distance of at least one meter, etc.

"Today, the first piece of advice we can give is hygiene: wash your hands. Second, avoid contacting anyone else. And thirdly, stay home as much as possible," Yap Boum II said (B. Kidiss, March 2020).

The consequence of these measures is the reduction of all activities of the planet in all fields. The same is true of blood donation, which is a voluntary and voluntary gesture in many countries.

Indeed, in the midst of the pandemic of covid-19, containment, quarantine and "limit your movements to essential activities" raise fears of a decrease in the number of blood donations. The week of the beginning of the confinement, on March 17, 2020, the EFS (French Blood Establishment) noted a 30\% decrease in the number of donations (Mr. Heshmati, April 11, 2020).

This can have serious consequences, because the reserves are not inexhaustible, as recalled by Mr. Villemur, doctor in charge of organizing collections at the EFS in Île-deFrance: "Blood products have a limited shelf life, 42 days for red blood cells and 7 days for platelets" (M. Heshmati, op cit, p.1).

In Cote d'Ivoire, Dr. Konate Seidou, the National Blood Transfusion Service (NBTS) Manager's noted that sampling activities had decreased by more than $70 \%$, thus undermining the capacity of the structure to meet the demand of healthcare institutions (ES) (NBTS, 2020a).

Based on these data, volunteerism has been strongly tested by the "stay home as much as possible" policy. So, what strategies have been implemented by the NBTS to respond to this drop in activity? The purpose of this study is to analyze the resilience strategies adopted by the NBTS aimed at reversing the trend of population participation.

\section{Research Methods}

\subsection{Type and Duration of the Study}

It's a qualitative study. It took place from May to December 2020. Data were collected from August to September 2020.

\subsection{Study Framework}

The study was conducted in blood establishments (ETS). There are 27 (4 BTS, 18 ATS and $5 \mathrm{SP}$ ) represented throughout Ivory Coast. 


\subsection{Population}

As part of our study, we interviewed the various HTA leaders, the head of the communications department, the transfusion services coordinator and the chair of the Scientific Advisory Committee (SCC). It has a staff of 30.

\subsection{Tool, Data Collection and Processing}

We used a maintenance guide as a data collection tool. For his information, we sent it via email to the various managers. Once the answers were received, we decided to use manual counting for their processing.

\subsection{Method of Analysis}

In this study, we used the systemic approach. Indeed, the systemic paradigm is based on the notion of a system which, according to Weinberg, is "a world path which looks at the world [...] a set of objects with the relations between objects and between their attributes" (1975, p. 52).

The central concept of systems management remains the organization, defined as "an arrangement of relationships between components or individuals that produces a new unit with qualities that do not have its components" (D. Durand, 1979, p. 9).

This approach has the merit of encompassing all the elements of the system under study and their interactions and interdependencies. In this regard, J.L. Le Moigne emphasizes that it is "as important to identify the whole, the totality of the elements and the relations between the elements, as to analyze independently the attributes of each of them" (1974, p. 9). These relationships can be of all kinds. Two main types of relations are transport and communications, which can be reduced into one. Communication is about transporting information, and transportation is about communicating materials, energy or information. Thus, interaction and feedback constitute the main relationships of phenomena.

Systemic control is an interpretative method of the functioning of human assemblies. It focuses on the forms of exchanges between actors, leaving aside many other psychological phenomena (which, in one way or another, are found in exchanges). It first updates a formal system of ritual exchanges between the actors of a situation that has been defined by a framework linked to the problem studied. It then proceeds to interpretations to understand how such a trading system works, and on what logic shared by the players it is based.

In order to understand the complexity of this social practice, the system, with its interpretation scheme, is rich and useful. Indeed, the NBTS, as a structure, can be analyzed as a system. Within this framework, systemic analysis is justified by the fact that it will consolidate both the structure as a whole, the agents, the partners and the population, from which the receptivity and impact of campaigns and promotion to blood donation can be measured.

\subsection{Theory of Resilience}

Dealing with this issue thus amounts to revisiting resilience theory. Indeed, the concept of resilience is used by different disciplines to analyze and manage the joint dynamics of ecosystems and social groups in the face of rapid and uncertain changes. Resilience refers to its ability to reorganize itself in the face of these changes (P. Buchheit \& al., 2016, C. C. Folke \& al., 2007; B.L. Turner \& al., 2003). 
Work on the resilience of socio-ecological systems often involves the adaptive cycle (see Figure 1), inspired by the dynamics of certain ecosystems. It represents the trajectory of a system in four phases. Each of them corresponds to a certain evolution of two characteristics of the system, its potential, or level of accumulation of resources, and the connectivity between its components (C.S. Holling, 2001). The resilience of the system would thus be at its maximum during the reorganization phase where, following the collapse of the system, new components and connections can emerge. This reorganization can even lead to a transformation of the system, i.e. a profound change in its structure, functions or identity. Resilience would be minimal when, after a consolidation phase, the system components become less diverse and more interconnected (S. Carpenter \& al. 2001; L.H. Gunderson, C.S. Holling, 2002).

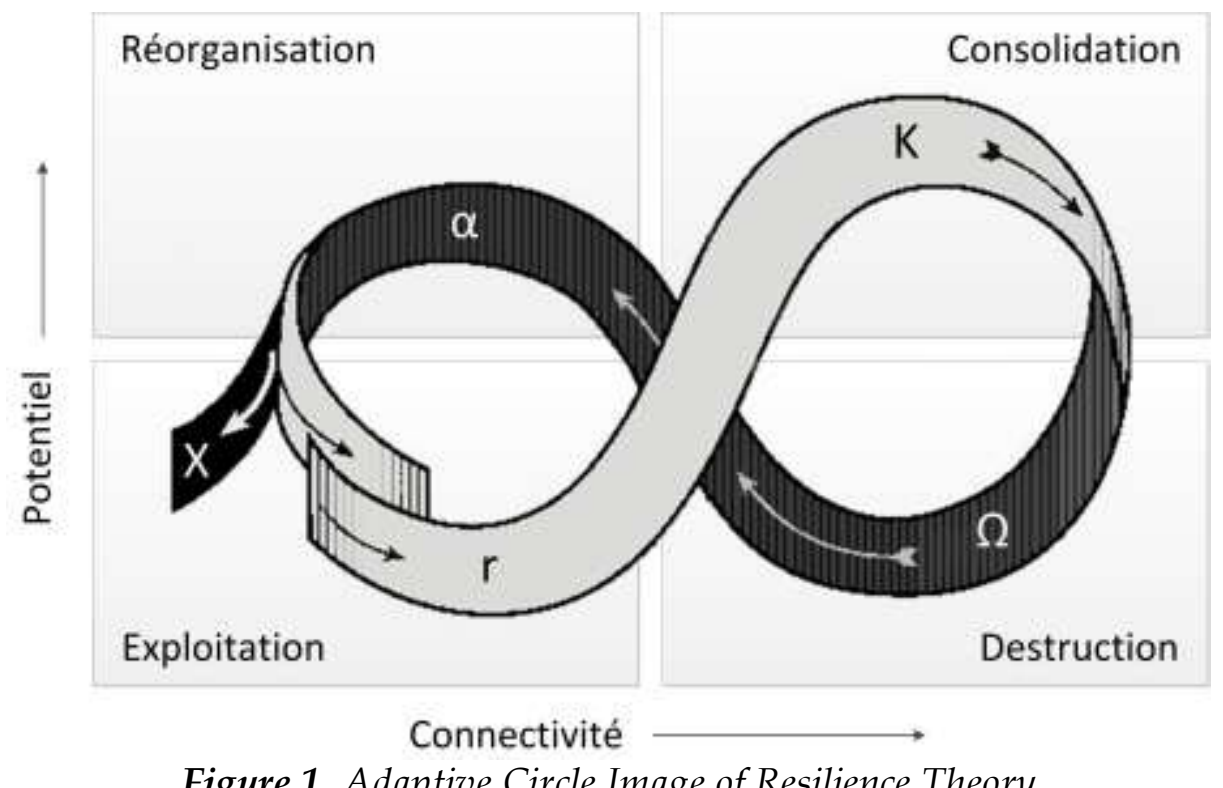

Figure 1. Adaptive Circle Image of Resilience Theory

Source: L.H. Gunderson \& C.S. Holling, op cit, $p .34$

\section{Results and Discussion}

\subsection{Results}

\section{a. Implementation of Health Barrier Measures}

In the fight against Covid-19, a response plan was adopted by the Ivorian State. It is structured in two axes: the barriers and the economic recovery plan. The first area of interest in this case is physical and health measures. The physical measures published by the ivorians authorities are:

- the blockade of greater Abidjan,

- containment,

- curfew,

- a state of emergency,

- the closure of the various borders,

- travel limits for essential activities,

- a ban on gatherings of more than 50 people,

- social distance of at least $1 \mathrm{~m}$,

- closures of venues, cults and restaurants. 
Health measures are composed of the following elements:

- regular hand washing,

- mask wearing,

- cough or sneeze in a disposable handkerchief or between the elbow,

- contact caregivers in the event of symptoms,

- avoid touching your face.

From 16 March to the end of April 2020, in implementing these measures, the NBTS canceled all mobile blood collection activities that represent more than half of its annual blood collection. In 2019, the NBTS data showed that it was $53.77 \%$. The impact on the sampling results was instantaneous. Indeed, before the outbreak of the Covid-19 epidemic, the NBTS collected on average 14,000 bags of blood per month over the territory. Since the screening of the 1st confirmed case (March 11, 2020) and the first government measures (March 16, 2020) to combat this pandemic in Côte d'Ivoire, a drastic drop in the samples has been observed. From 3,500 levies per week before that date, 1,300 levies in week 3, a decrease of one third and 269 levies in week 4, a decrease of $1 / 13$ were recorded (see figure 2).

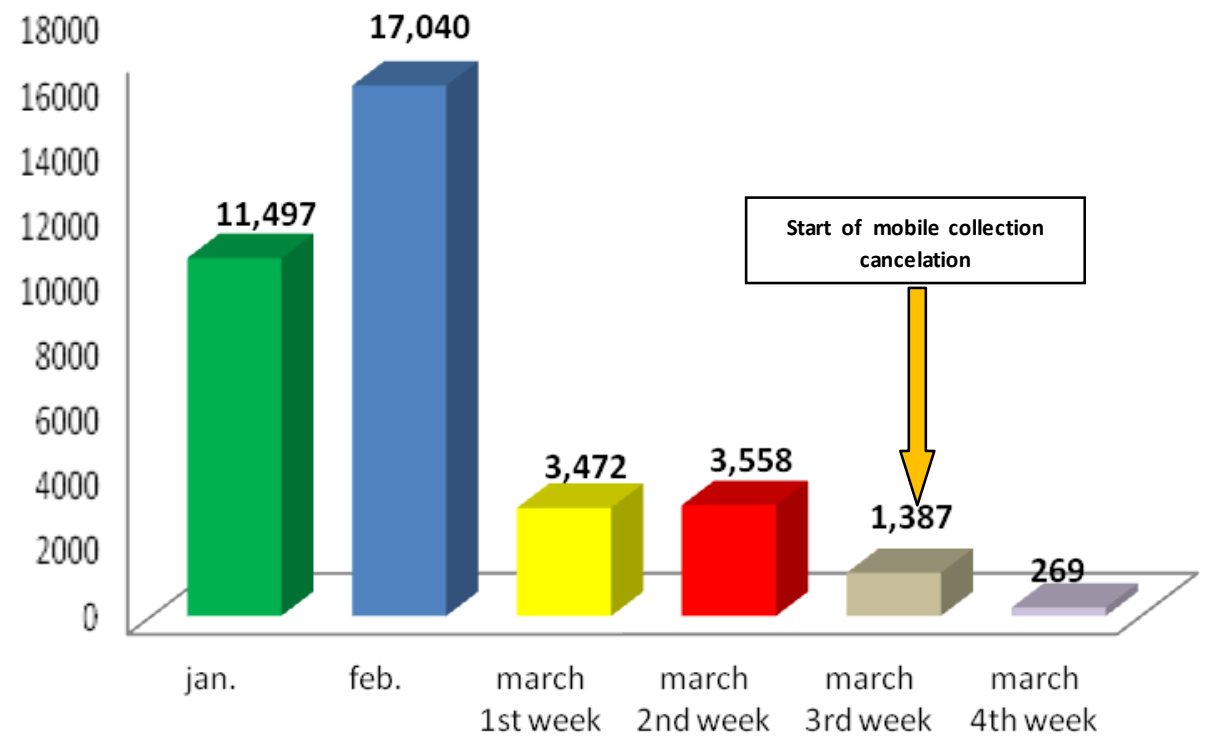

Figure 2. Evolution of Blood Samples in Cote d'Ivoire from January to March 2020 Source: CNTS, 2020

These cancelations were due, on the one hand, to the problems of implementing the measures barriers at these mobile blood collection sites, to the concerns and fears of welcoming in their respective companies and structures the agents of the NBTS, the closure of schools and universities. On the other hand, the requirement for the deployment of a mobile collection team was for organizations to be able to gather on site 100 and more potential donors. The ban on gatherings of more than 50 people has undermined this requirement.

At fixed sites (BTS, ATS, SP), sanitary facilities have been set up. These include hand washing equipment (seefigure 3), the use of thermal thermometers (see figure 4) and the wearing of masks in both donors and staff (see figure 3). 


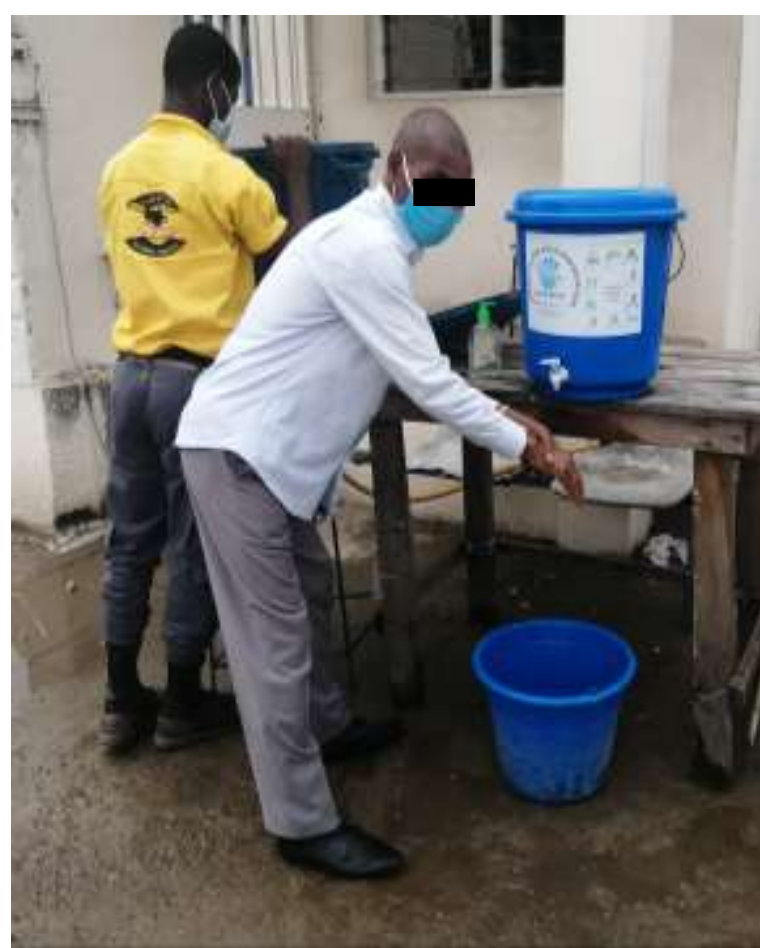

Figure 3. Hand Washing Device

Source: Our survey, 2020

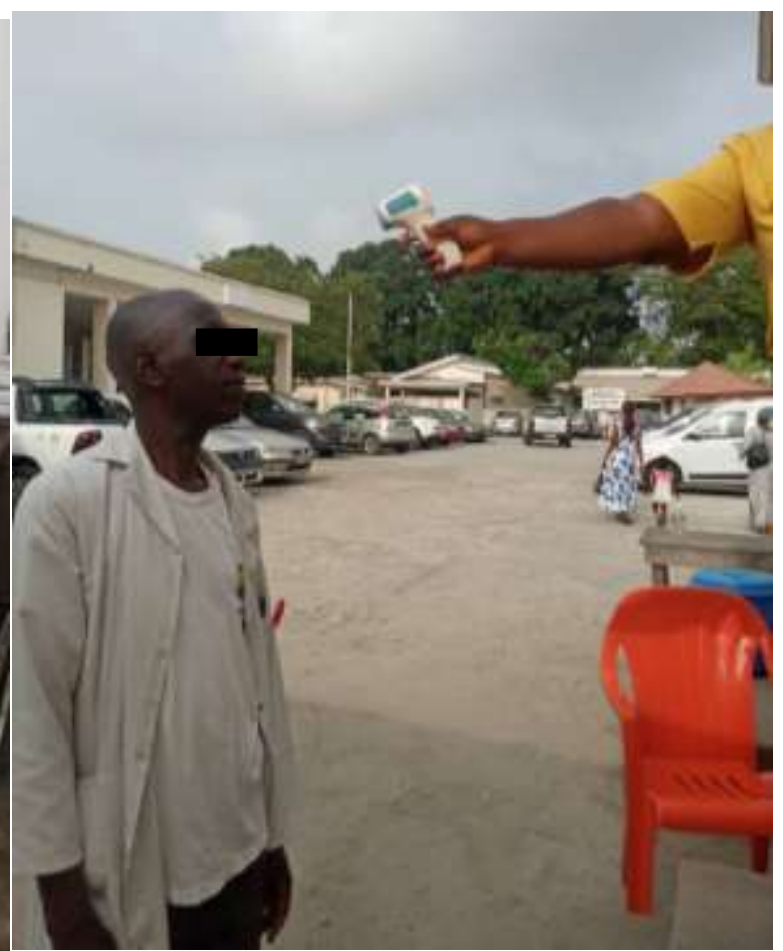

Figure 4. Temperature Capture at NBTS' entrance Source: Our survey, 2020

\section{b. Resilience of the NBTS}

Faced with the decline of its activities and the growing demand for blood products, the management of the NBTS has set up a Scientific Advisory Committee (CSC) which has reflected on the resilience strategies. Next, it organized about ten meetings to measure the impact of Covid-19 and monitor activities. Finally, it has adopted various measures.

\section{c. Dynamic Communication Strategy for Encouraging Blood Donation and Rational Use of Blood Components}

Communication plays an essential role in human activities. Its impact is well documented. It is even more important in voluntary, voluntary and unpaid activities such as blood donation.

In view of this fact, the NBTS has, on the one hand, taken steps with the RTI (Ivorian Radio Television) Directorate that have led to a considerable reduction in communication costs. In addition, it sought the support of partners in the implementation of its emergency communication plan. These supports have helped to finance the costs of advertising spots, advertisements, advertisements on public media such as RTI (RTI 1, RTI 2, la 3, Radio Côte d'Ivoire and Frequency 2).

This support has led to an increase in NBTS communication activities. As a result, the frequency of awareness-raising for encouraging people to donate blood improved significantly over the period from mid-April to July 2020.

A Google search with the MeSH Terms "RTI", "blood donation" and "covid-19" allows to capture the quality and quantity of the actions that have been carried out over the period covid. For example, we have, in two parts, the program "Our Health" dedicated to the NBTS. ... period of health crisis by giving a little of our blood whose title was: "I want to donate my blood during COVID-19 but I am afraid of being contaminated" broadcast on Monday, June 17 
and September 14, 2020 on RTI 1 after the 8 p.m. RTI reports "Blood Bank: Donors are scarce RTI 1"; "Boigny's Day' for blood donation and saving lives"; "Bonake: The interns' association donates blood to hospitals", etc.

In addition to these incentives to blood donation, measures to promote blood savings and the rational use of blood components were also considered. These included:

"to strengthen collaboration between clinicians, blood shed managers and transfusion structures to better manage patients for transfusion and to minimize non-emergency transfusions and to raise awareness in clinical services about the optimal use of highly restricted resources in the event of a pandemic" (Source: CSC_P).

At the local level, these measures were implemented as noted by the CTS_Y respondent:

"Awareness was also raised with the Hospital Directors and BDS Manager. To this end, awareness-raising letters for the efficient management of the blood stocks at their disposal bave been transmitted to them and amplified to the Regional Health Directorate."

\section{d. Reorganization of Blood Collection at Fixed Sites}

Typically, fixed collection activities are carried out from Monday to Saturday from 07:30 to 12:00 with several agents at the different posts in order to reduce the time of blood donation.

At the end of the management meetings, a reorganization of the activities of the fixed collections was carried out. It concerns the number of staff at the different posts and the hours/days of the samples.

For the first, a rotation of the agents at the different posts was selected and applied as a response to the social distance of at least $1 \mathrm{~m}$.

As for the second, an extension of sampling times and working days was observed. In fact, the work schedule of the aforementioned service has been extended to "13 or 14 hours depending on the influx of blood donors" (Source: ATS_K \& CSC_P).

In addition, scheduling blood donors by appointment was a strategy adopted as evidenced by the CTS_Y and CST_T respondents:

"At first, we made the list of potential donors and their contacts available to the STC secretariat. Then we decided to call the donors to talk and reassure them instead of a message (SMS). With the appointments obtained, we took stock of the situation on a daily basis". (Source:CTS_Y).

"The NBTS's IT department was responsible for providing a list of potential donors with their contacts throughout the country. The list was then handed over to the office of the National Union of Volunteer Blood Donors of Côte d'Ivoire (UNADSCI) who sent it who through SMS or call sending had the task of inviting these donors to make a donation in the nearest structure". (Source: CTS_T).

In the first case, the activity was performed at the local level. However, in the second, the scope was national. In addition, activities could be held on Sundays if organizations, associations or communities expressed a desire to donate blood. Thus, "over the period, several Sunday activities were carried out on the Treichville BTC" confirmed the respondent CSC_P. 


\section{e. Reorganization of Mobile Blood Collection Activities}

To resolve the ban on gatherings of more than 50 people, the NBTS management has adopted the strategy of splitting up mobile collection activities at the various sites. This strategy consisted of "planning at the same collection site for several days of activity until the collection target set by the collection organizer is met" (Source: BST_T). Thus, for an activity with a forecast of 100 people, two days are required to conduct it. This strategy has enabled the resumption of mobile collection activities, a real lever for the achievement of the NBTS target.

The implementation of these different strategies has led to a quantitative relaunch of NBTS levies. Indeed, Figure 3 unambiguously shows two trends: a drop in blood samples from mid-March to April 2020, which corresponds to the application of the measures leading to the cancelation of mobile blood collections and a phase of upward blood samples from May 2020, which corresponds to the period of implementation of the resilience measures and thus to the resumption of mobile blood collections. The samples from this phase have reached the average of NBTS samples as shown so well by the level of the curves of the months of June-July with that of February 2020.

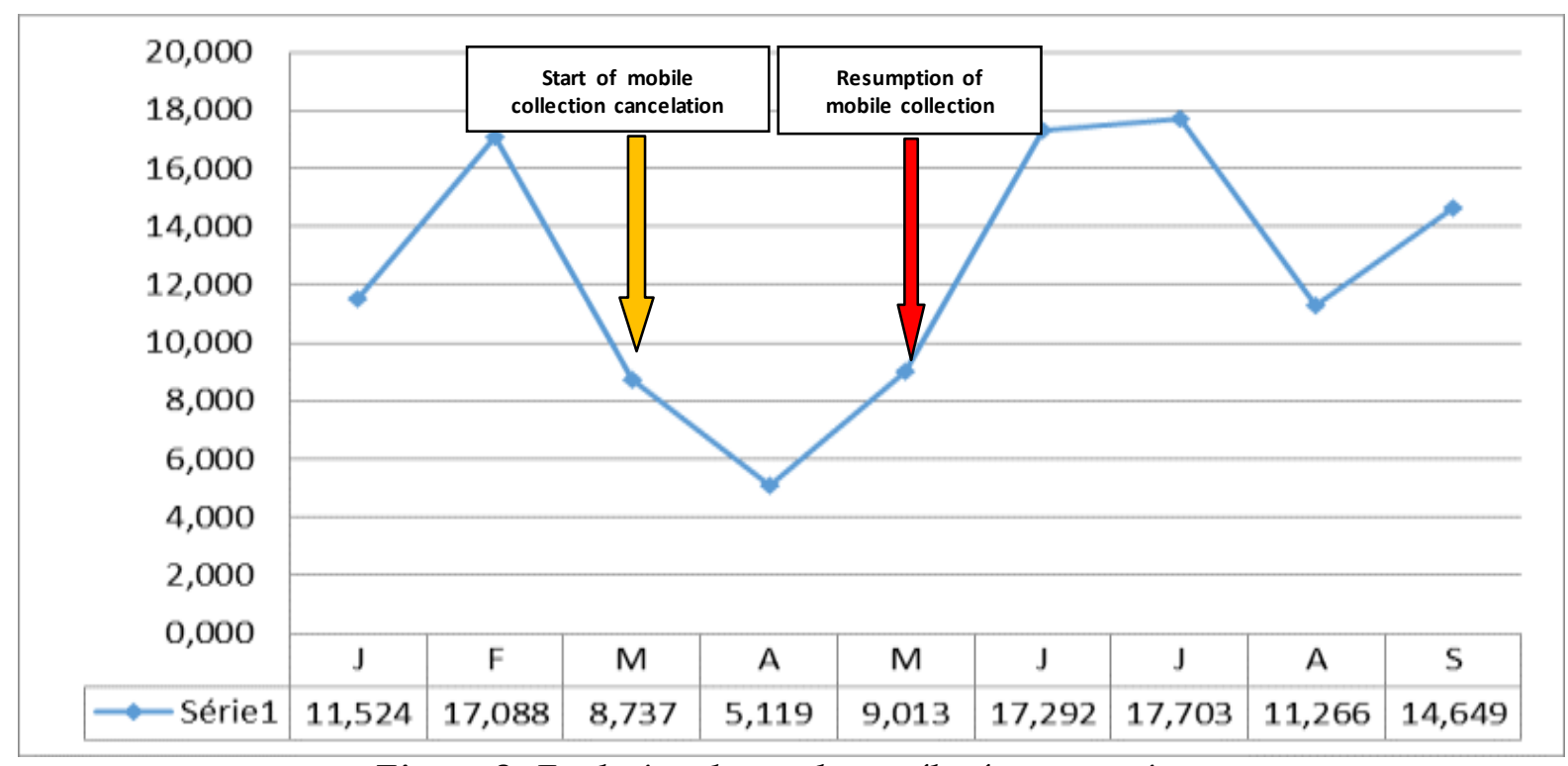

Figure 3. Evolution des poches prélevées par mois

Source : NBTS, $2020 b$

\subsection{Discussion}

It is undeniable that the Covid-19 crisis has been a shock not seen for the whole world and has taken its toll on the individual as well as on the private and professional level. Indeed, all sectors in the world such as education system (T.N. Mandola \& al, 2021), economic system (M.M Modeawi \& al, 2021; ILO, 2020a), social organization (ILO, 2020b), health system (D. Safrina \& al, 2021; WHO, 2020a), etc. have affected negatively.

Therefore, the field of blood transfusion is not spared. Indeed, the worries about declining blood donations that have been felt around the world have materialized into a real decline in blood donations during the Covid 19 pandemic, to the point that several countries have warned of the dramatic consequences of a decline in national reserves in blood banks. Indeed, the restrictive measures imposed in several countries to limit the spread of the coronavirus have led to the cancelation of thousands of scheduled mobile blood collections due to the closure of schools but also of certain collection sites. 
The results of our study are confirmed by the intervention of F. Ahlonsou, of the National Agency for Blood Transfusion in Benin, who noted that "a country like Benin, which has not taken the option of strict containment, is also facing a decline in blood donations. [Because] donors no longer want to move to health facilities" (C. Assignon, April 2020, p1).

Thus, in the face of pandemic covid-19, resilience was observed in the case of blood transfusion. Indeed, "this pandemic was an opportunity for companies to invent new ways of operating and organizing in a few days" (C.-H. Besseyre des Horts refered by S. Frimousse, J-M. Peretti, 2020a, p.113). For, "the managers and the collaborators were forced to leave their comfort zone, break with their habits, their routine reflexes, their respective roles and their customary behaviors. Reinventing the organization, adapting it, readjusting it, putting it in the image of today's world (...) and above all allowing it to survive are the challenges that this crisis has helped to identify", noted Z. Attya (S. Frimousse, J-M. Peretti, 2020a, p.110). Thus, "in an emergency, a reorganization of the work was put in place" noted L. BenraïsNoailles (S. Frimousse, J-M. Peretti, 2020b, p.171).

Therefore, in the specific field of blood transfusion, the ETS adapted to the various measures taken to prevent the spread of the disease. First, they canceled all mobile collection activities in order to get control of the sanitary conditions before devoting themselves to them. This fact is confirmed by F. Ahlonsou who explained the cancelation of mobile collections by: "as part of the mobile teams' blood collection, when you move around, people are in large numbers and it's dangerous. Protective measures are more difficult to take outside the blood transfusion structure. [...] They are afraid to welcome us into their businesses, into their respective structures so that we can make the collections" (C. Assignon, op cit, p1).

Secondly, a reorganization of activities was noted. Because " it is always possible to donate blood during confinement. It is even essential to avoid a lack of blood products that could be fatal to patients who depend on them. [...] It is therefore essential that donors be collected every day. And for these collections to continue despite the coronavirus-related confinement, practical information must circulate: the French always have the right to go out and donate their blood," said Mr. Heshmati (April 2020, p1).

One of the first actions was to secure fixed sites by setting up hardware. This was found in the sub-region's HTAs. Thus, F. Ahlonsou noted: " A safety that requires the installation of hand-washing devices and the wearing of protective equipment by the nursing staff" (C. Assignon, op cit, p1).

The second was to "reassure blood donors" through the mobilization of communication. This strategy was designed to remove the fear of being contaminated at blood sites. This was the case in Burkina Faso and Togo. In the first case, "national blood transfusion centers specify that donation sites are secure so as not to expose potential blood donors to risks of contamination with covid-19" (C. Assignon, ibid., p1).

In Togo, the artist Agbleta Kokou, known as Gbadamassi, himself a blood donor, who says he understands these fears "Everyone is a suspect, the doctor is afraid to contract the disease as I am also afraid of him. I think they will have to put in place security measures" (C. Assignon, ibid, p1) was mobilized to dispel these doubts.

This strategy is in line with the WHO guidelines (2020a), which stated that " a dynamic communication strategy must be launched quickly in the face of donor anxiety, which often stems from a lack of information, the consultation of erroneous information or the fear of being infected during donation. Effective campaigns must be conducted continuously to raise public awareness of the importance of maintaining an adequate supply at the national level, the need for blood donors and the security of the donation process. It is 
important that the public and stakeholders have confidence in the blood system. The blood service must adopt clear communication to ensure that the national emergency response team, donors and recipients, and the public are properly informed and understand the planned measures" (p.2).

Third action has been to change the practices both in the organization of work, working hours as the WHO has indicated (2020a). Indeed, faced with the difficulties resulting from "containment strategies [that] may make it more difficult for donors to go to collection points and prevent collection teams from going to areas where clusters of cases or where restrictions are in place for public health reasons. (...), it may be possible to quickly switch to other collection sites (if possible), transport donors, intensify appointments or change schedules" (WHO, 2020a, p3).

This reality was observed by Hema-Québec (2020). Indeed, Hema-Québec changed its practices because of the COVID-19 pandemic "by asking anyone who wishes to donate blood to make an appointment by calling or sending an email. [In addition], many security measures are deployed throughout the collection sites to make blood donation a safe experience. Hema-Québec pays particular attention to the safety of donors, volunteers and employees, by applying, in particular, the measures [i.e.] of controls on access to collection sites with temperature-taking of donors, volunteers and employees carried outprior to access to the site, the disinfection of screens used for the blood donation qualification questionnaire, as well as that of the collection beds, a revised collection logistic organization in order to comply with the measures of distancing, the addition of acrylic panels in all collection sites, the wearing of surgical masks, given by Hema-Québec, mandatory for all (employees, volunteers and donors) at all times"(p1).

\section{Conclusion}

The covid-19 pandemic forced all organizations to adapt. These responses have gone through two phases. The first was the slowdown or cancelation of various activities. The second was the resilience phase. The NBTS of Côte d'Ivoire has not been on the sidelines of this sad reality. He has adopted three resilience strategies that have enabled him to meet the therapeutic blood product needs of the Health Care Facilities.

\section{References}

Assignon Carole, April 2020, Concerns in Africa about declining blood donations, dw, https://p.dw.com/p/3bBsb

Buchheit Pauline, D'AQUINO Patrick, DUCOURTIEUX Olivier, 2016, Theoretical frameworks mobilizing the concepts of resilience and vulnerability, Vertigo, the Electronic Journal in Environmental Sciences, available at https://doi.org/10.4000/vertigo.17131

Carpenter Steve, WALKER Brian, ANDERIES John M., ABEL Nick, December 2001, "From Metaphor to Measurement: Resilience of What To What?", Ecosystems, 4(8):765-781, DOI: $10.1007 / \mathrm{s} 10021-001-0045-9$

Durand Daniel, 1983, The systematic, Paris, Presses Universitary of France, coll. What do I know? 1795.

Folke Carl, Pritchard Lowell, Berkes Fikret, Colding Johan, Svedin Uno, 2007, “The problem of fit between ecosystems and institutions: ten years later", Ecology and Society, 12(1):30, [Online] URL: http://www.ecologyandsociety.org/vol12/iss1/art30/

Frimousse Soufyane, Peretti Jean-Marie, 2020a, "The organizational changes brought about by the COVID-19 crisis", Revue Question(s) de management, 2020/3, n²9:105-149, ISSN 2262-7030, [Available at] https://www.cairn.info/revue-questions-demanagement-2020-3-page-105.htm 
Frimousse Soufyane, Peretti Jean-Marie, 2020b, "The lasting repercussions of the crisis on management", Revue Question(s) de management, 2020/2, n 28:159-243, ISSN 22627030, [Available at] https://www.cairn.info/revue-questions-de-management-2020-2page-159.htm

Gunderson Lance H., Holling Crawford Stanley, 2002, Panarchy: understanding transformations in human and natural systems, Island Press, Washington, D.C., USA.

Hema-Quebec, 2020, Hema-Quebec in the context of a pandemic, Montreal, [Available at] https://www.hema-quebec.qc.ca/coronavirus/hema-quebec-in-context-ofpandemie/faq.fr.html

Hema-Quebec, June 2, 2020, 100 more blood donations needed every day: Hema-Québec asks blood donors to be numerous in June, Montreal, [Available on] https://www.hemaquebec.qc.ca/publications/communiques/archives/2020/ communiques-2020/100dons-de-plus-chaque-jour-en-juin.fr.html

Heshmati Mandi, 11 April 2020, Blood donation, an essential act even during the coronavirus, France 24.

Holling Crawford Stanley, August 2001, "Understanding the Complexity of Economic, Ecological, and Social Systems”, Ecosystems, 4(5):390 -405, DOI: 10.1007/s10021001-0101-5

International Labour Organization (ILO), 2020a, International Labor Organization (ILO) Observatory, COVID-19 and the world of work, 4th edition, Geneva.

International Labour Organization (ILO), 2020b, Social Protection Spotlight, Social protection responses to the COVID-19 pandemic in developing countries: Strengthening resilience by building universal social protection, Geneva, $14 \mathrm{p}$

Johns Hopkins University, 2020, Covid-19 Global map, [Available at] https://coronavirus.jhu.edu/map.html

Kidiss Badr, March 2020, Coronavirus in Africa: "Stay home as much as possible", AlloDoctorsAfrica

[Available at] https://allodocteurs. africa/actualities/epidemie/covid-19/coronavirusin-africa-stay-home-as-much-as-possible

Le Moigne Jean-Louis, 1974, Decision Systems in Organizations, Paris, PUF, 244 p.

Madandola Tajudeen Niyi, Salawu Omotayo, Sakariyau Sherif Niyi, Owolabi Oyebola Oyekemi, Madandola Monsurat Oluwabukola, April 2021, "A Year Emergence of Covid-19 in Nigeria and Its Consequences on Educational Development of Kwara State", Budapest International Research in Exact Sciences, Volume 3, N²:98-106, ISSN : 2655-2647 (Print), ISSN : 2655-1470 (Online)

Modeawi Modeste Ndaba, Mawi Clarisse Falanga, Nyante Urbain Mazo \& al, 2021, COVID19 Pandemic: Opportunity for a True Economic and Regional Integration of Africa, Budapest International Research in Exact Sciences, vol 3, n² : 143-151, ISSN : 26552647 (Print), ISSN : 2655-1470 (Online)

National Blood Transfusion Service (NBTS), 2020a, Technical Note to the Minister of Health and Public Hygiene, Abidjan

National Blood Transfusion Service (NBTS), 2020b, Activity Report of the National Blood Transfusion Service from January to September 2020, Abidjan

Safrina Dince, Dewi Oktavia, Nurlisis, Mitra, Damayanti Ika Putri, February, 2021, Analysis of Factors that Correlated with Anemia Incidence in Pregnant Women at Working Area of the Sidomulyo Health Center Outpatient UPTD Pekanbaru City, Britain International of Humanities and Social Sciences, Vol 3, $n^{0} 1: 105-114$

Society Of Blood, 2020, Transfusion Recommendations for blood establishments regarding the novel coronavirus disease (COVID-2019) outbreak (v1.0) (English translation), Chinese, [Available on] http://eng.csbt.org.cn/portal/article/index/id/606/cid/7.html. 
Turner Ii B L, Kasperson Roger E, Matson Pamela A., et al, August 2003, “A framework for vulnerability analysis in sustainability science", Proceedings of the National Academy of Sciences, 100(14):8074-9, DOI: 10.1073/pnas.1231335100

Weinberg Gerald Mark, 1975, An introduction to general system thinking, New York: Wiley Inter Science.

World Health Organization (WHO), 2018, Risk Communication during Health Emergencies, Geneva, [Available at] https://www.who.int/publications-detail/communicating-riskin-public-health-emergencies.

World Health Organization (WHO), 2020a, Maintaining a Safe and Adequate Blood Supply during the 2019 Coronavirus Pandemic (COVID-19) - Interim Guidance, Geneva.

World Health Organization (WHO), 2020b, Advice on the use of masks in the community, during home care, and in health care settings in the context of COVID-19, Geneva, [Available at] https://www.who.int/publications-detail/advice-on-the-use-of-masksin-the-community-during-home-care-and-in-healthcare-settings-in-the-context-of-thenovel-coronavirus-(2019-ncov)-outbreak.

World Health Organization (WHO), January 26, 2020, Communication on Risks and Community Involvement $(\mathrm{CCHN})$ : preparation and response to the new coronavirus 2019 (2019-nCoV). Draft Guidelines, Geneva, [Available at] https://apps.who.int/iris/bitstream/handle/10665/330679/9789240000797-fre.pdf

World Health Organization (WHO), January 30, 2020, Declaration on the Second Meeting of the Emergency Committee of the International Health Regulations (2005) concerning the outbreak of new coronavirus 2019 (2019-nCoV), Geneva, [Available at] https://www.who.int/fr/news/item/01-30-2020-statement-on-the-second-meetingof-the-international-health-regulations-(2005)-emergency-committee-regarding-theoutbreak-of-novel-coronavirus-(2019-ncov) 